\title{
Occupational Safety and Health of Coal Mine Workers in Kenya: Filling the Lacuna in the Law
}

\author{
Ikoha Muhindi*
}

\begin{abstract}
Mining is essential in the economic development of any country endowed with mineral resources. In Kenya, for instance, one block of coal in the Mui Basin has enough coal to bring in KES. 3.4 trillion into the economy. However, disasters such as the Monongah disaster in a coal mine in the United States have resulted in the loss of lives of numerous workers. It is therefore important to ensure the enactment of legislation safeguarding these workers. This article seeks to assess the extent to which the Occupation Safety and Health Act safeguards these concerns in Kenya. It also undertakes a brief comparative study of the best practices employed in Australia and South Africa in safeguarding the safety and health of workers in coal mines. Finally, the article makes recommendations on how Kenya can follow suit and adopt various aspects of the legislations from these jurisdictions.
\end{abstract}

\section{Introduction}

Mining is defined as the process of extracting precious or valuable metals from the earth, and this extraction can either be in its native state or in their ores. ${ }^{1}$ In many developing countries, such as Kenya, mining is a contributor to revenue in the economy and provides employment to the locals in the area. ${ }^{2}$ In 2012, the Kenyan Government discovered coal deposits in Mui Basin, Kitui County. According to the information provided by the Ministry of Energy (as it then

* The author is an LL. B graduate from the Strathmore University Law School in Nairobi, Kenya.

Re Rollins Gold Mineral Co. (D.C.) 102 Fed. 985.

2 See Malisa E and Kinabo C, 'Environmental risks for gemstone miners with reference to Merelani Tanzanite mining area, Northeastern Tanzania' 31 Tanzania Journal of Science (2005). 
was), block $\mathrm{C}$ alone has an estimated 400,000 metric tons of coal deposits. ${ }^{3}$ This is enough to earn KES. 3.4 trillion, at current market rates. ${ }^{4}$

However, by its nature, coal mining is intrinsically one of the most dangerous lines of occupation. This is because of the following reasons: ${ }^{5}$ First, coal is readily inflammable and explosive especially in its finest form and frequently, coal mines contain highly flammable and explosive gases. In some cases, non-flammable gases may be present in the coal mines which can kill a coal worker inhaling the gases through suffocation. Second, the sinking and tumbling of roofs in coal mines frequently occur and approximately cause four times as many fatalities as explosions. Third, the coal mining process, regardless of whichever method is employed, involves the use explosives on the coal deposits. ${ }^{6}$ These, coupled with untold amounts of dust, are ready ingredients for sicknesses such as lung diseases, skin rashes and eye infections. ${ }^{7}$

Disasters in coal mines often tend to be of a high magnitude and have led to countries and international organizations making legislations safeguarding the safety and health of coal workers in their various jurisdictions. For instance, the Monongah Mining Disaster, which resulted in the death of 362 workers as a result of an underground explosion led to creation of an institution known as the United States Bureau of Mines in 1910 whose sole purpose was to improve the safety in mines and was followed by the Federal Coal Mine Health and Safety Acts enacted in 1969 and 1977 respectively. $^{8}$

Kenya's legal framework recognises the importance of the safety and health of workers. The Constitution of Kenya, 2010 (hereinafter the 2010 Constitution) accentuates that every worker has the right to fair labour practices which include the right to reasonable working conditions. ' This article highlights that reasonable working conditions include all conditions necessary to ensure that the safety and health of workers are safeguarded. ${ }^{10}$ The Occupational

3 Mutemi A, 'Mui coal mines: A blessing or a curse? Socio-economic and environmental intricacies' University of Nairobi (2013), 3.

4 Mutemi A, 'Mui coal mines', 3.

5 Harrington D, 'Safety in coal mining' 123 The Annals of the American Academy of Political and Social Science, Industrial Safety (1926), 93.

6 Jahnig A 'Coal deposits of Colombia' Freiberg University of Mining and Technology (2007), 9.

7 Colagiuri R, Cochrane J and Girgis S, 'Health and social harm of coal in local communities- Spotlight on the Hunter region' Beyond Zero Emissions (2012).

8 http://www.metallixrefining.com/harmful-effects-of-mining-and-viable-alternatives/ on 5 January 2016.

Article 41(1), Constitution of Kenya (2010).

Article 41(2) b, Constitution of Kenya (2010). 
Safety and Health $\mathrm{Act}^{11}$ and the Work Injury Benefit Act, ${ }^{12}$ have tried to regulate the manner in which employees are treated and the various penalties employers face for negligence on their part in ensuring that employees are working in good conditions. However, as is later demonstrated in this article, the existing laws are still insufficient to adequately cater for the safety and health of workers in coal mines. Further, the article shows the need for our country to follow the examples set by other countries in protecting the safety of coal workers in the mining industry.

\section{The Legal Framework on the Occupational Safety and Health of Coal Workers in Kenya and its Shortcomings}

In Kenya, the legal framework governing coal workers is enshrined in the 2010 Constitution, Acts of Parliament and legal policies.

\section{i. The Constitution of Kenya, 2010}

The 2010 Constitution ${ }^{13}$ is the grundnorm ${ }^{14}$ of the state and as such, ranks highest in relation to other sources of municipal law in the state. ${ }^{15}$ In its preamble, the 2010 Constitution accentuates the significance of all persons' well-being as all citizens ought to be committed to nurturing and protecting the well-being of the individual, the family, communities and the nation. ${ }^{16}$ It highlights that all workers have the right to reasonable working conditions. ${ }^{17}$ Further, each individual has the right to the highest attainable standard of health. ${ }^{18}$ This shows the high value the 2010 Constitution places on the safety and health of workers including those in coal mines.

Additionally, Article 66(1) of the 2010 Constitution stipulates that the State has the authority to regulate land and any interests arising over land in safeguarding public safety and health. This can be interpreted to mean that the State has

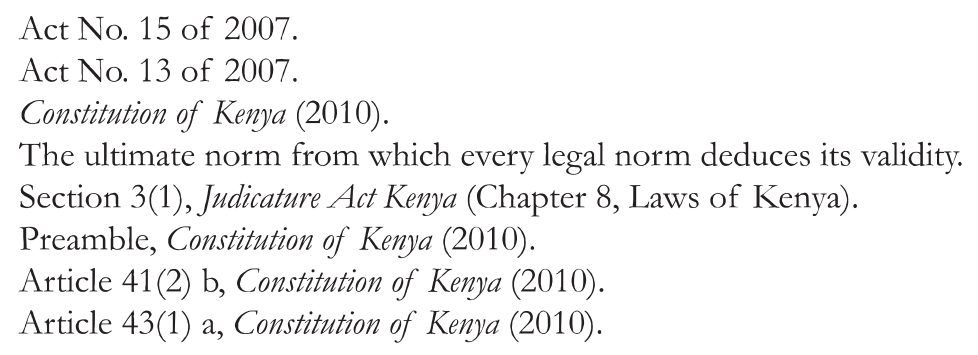


the power to stop the operation of a mine if it poses a risk to the health of the workers or it can compulsorily acquire the mine.

The 2010 Constitution has provided for a recourse mechanism a person may turn to if their right to a clean and safe working environment has been infringed or violated. It states:

'If a person alleges that a right to a clean and healthy environment recognised and protected under Article 42 has been, is being or is likely to be, denied, violated, infringed or threatened, the person may apply to a court for redress in addition to any other legal remedies that are available in respect to the same matter. ${ }^{319}$

The Industrial Court has jurisdiction to hear matters pertaining to enforcement of occupational safety and health rights. This is pursuant to Article 162(2) of the 2010 Constitution which gives Parliament the power to establish courts to hear and determine disputes relating to employment and labour relations. These courts have the same status as the High Court. The Court has exclusive original and appellate jurisdiction to hear and determine all disputes relating to employment and labour relations. ${ }^{20}$

\section{ii. Acts of Parliament}

\section{a. The Occupational Safety and Health Act}

The Occupational Safety and Health $\mathrm{Act}^{21}$ is a statute whose aim is, inter alia, to provide for the safety and health of workers in their workplaces and to provide for the establishment of the National Council to cater for issues pertaining to occupational safety and health. ${ }^{22}$ It outlines the duties of an employer in ensuring the safety and health of all persons working or present in their workplace. ${ }^{23}$ These duties include the provision and maintenance of safe systems, facilities and procedures of work, providing any information, training or supervision that may be required in ensuring the safety and health of all the employees, availing information on any risks that may be associated with new technologies and finally, employers have to make sure employees participate in the application and review of safety and health measures in relation to the workplace. ${ }^{24}$

\footnotetext{
Article 70(1), Constitution of Kenya (2010).

Section 12, Industrial Court Act (Act No. 20 of 2011).

Occupational Safety and Health Act (Act No. 15 of 2007).

Preamble, Occupational Safety and Health Act (Act No. 15 of 2007).

Section 6(1), Occupational Safety and Health Act (Act No. 15 of 2007).

Section 6(2), Occupational Safety and Health Act (Act No. 15 of 2007).
} 
Further, as a precautionary measure, the Act stipulates that risk assessments on the safety and health of employees have to be carried out by the employer, and after the results are examined, the employer has to come up with measures that will ensure that all equipment and tools used in the workplace are safe and do not pose any risks to the safety and health of employees. ${ }^{25}$ The duties provided for by the Act are twofold as employees also have a duty to ensure that their personal safety and health, as outlined in Section 13, is protected. In doing so, they have to ensure the following: That they have worn protective clothing on their person as they work, they have to fully comply with safety and health procedures and instructions provided to them and they have to report promptly to their supervisor any situation that they have sufficient reason to believe will pose a danger to their safety and health. ${ }^{26}$

In spite of the express provisions provided for by the law on the obligation employees have in safeguarding their own safety and health, it has proved difficult for employees in mines, especially those in developing countries such as Kenya to adhere to these obligations. This is because, despite having the express right to remove themselves from any situations that may pose a risk to them, employees face another risk; that of losing their jobs as a result of doing so. ${ }^{27}$ For instance, on 5 May 2007, a Company dismissed 28 workers as a result of striking because of poor working conditions. Fortunately, the Kenya Plantation Union with the backing of the Minister of Labour at the time, fought for the reinstatement of the workers. ${ }^{28}$ Similarly, coal mine workers may not be inclined to leave the mines even if the working conditions do pose a danger to their welfare as they would not want to lose their source of income. Another example was seen in Kenya Quarry and Mines Union v Kenya Calcium Products Ltd, ${ }^{29}$ where legal counsel for these mining corporations took advantage of the ignorance of the employees in the mines. In this case, the grievants incited the other employees to go on strike. However, failure to follow the set out grievance mechanism in their collective bargaining agreement led to their summary dismissal.

The Act has faced a major problem in its implementation. Kenya has a population of 38.6 million people. ${ }^{30}$ Of these, 2 million work in the

\footnotetext{
Section 6(2), Occupational Safety and Health Act (Act No. 15 of 2007). Section 6(2), Occupational Safety and Health Act (Act No. 15 of 2007). http://www.state.gov/documents/organization/160127.pdf on 29 December 2015. The annual survey of violation of trade union rights in Kenya, 2007. Kenya Chemical and Allied Workers Union v Pyretbrum Board of Kenya [1989] Gazette Notice No. 3315. Kenya population data sheet, 2011 (These are the figures tabulated after the 2009 census).
} 
formal sector and 8.8 million work in the informal sector. ${ }^{31}$ There are about 140,000 workstations situated throughout the country and the Directorate of Occupational Safety and Health Services (hereinafter the Directorate), with 71 professional occupational safety and health officers, is not capable of effectively inspecting the workstations leaving many workers exposed to occupational safety and health hazards without intervention. ${ }^{32}$ Further, the representation of the Directorate in 29 counties leaves the remaining 18 counties without any officers. $^{33}$

Additionally, in rural areas, literacy levels are very low and as seen, are insufficiently covered by the Directorate. This leaves most, if not all, of these workers ignorant of the minimum requirements of safety and health set by the government. Most therefore end up working in unsafe conditions and are left exposed to occupational safety and health hazards. ${ }^{34}$ From the above, it can clearly be seen that the Directorate is unable to effectively cater for workers in coal mines as it lacks the necessary capacity to do so.

Therefore, there is need for the office of the Directorate to introduce new specialised institutions which will cut across all ministries and carry out the work of inspection of various workplaces that fall within the ministries.

\section{b. The Work Injury Benefits Act}

The Work Injury Benefits Act is an Act of Parliament enacted with the purpose of compensating employees who are injured at work and contract diseases connected with their employment. ${ }^{35}$

It defines an employee as a person working under a contract of service. ${ }^{36}$ Workers in coal mines fall under this definition and therefore fall under the Act. It entitles an employee to compensation as a result of an accident which has led to the disablement or death. ${ }^{37}$

31 International Labour Organization 'National profile on occupational safety and health - Kenya' (2013).

32 International Labour Organization 'National profile on occupational safety and health - Kenya' (2013).

33 International Labour Organization 'National profile on occupational safety and health - Kenya' (2013).

34 International Labour Organization 'National profile on occupational safety and health - Kenya' (2013).

35 Preamble, Work Injury Benefits Act (Act No. 13 of 2007).

36 Section 5(1), Work Injury Benefits Act (Act No. 13 of 2007).

37 Section 10(1), Work. Injury Benefits Act (Act No. 13 of 2007). 
The Act makes it illegal for an employer to solicit contributions from employees towards the cost of medical aid. ${ }^{38}$ It is considered an offence and the Director of Occupational Safety and Health Services has the authority to issue orders compelling the employer to pay back any amounts that may have been taken. ${ }^{39}$

The Act, however, fails to provide adequate compensation for persons, such as coal workers who may be injured permanently as a result of explosions and other accidents that may paralyse them; leaving them unable to work again. This issue shall be further expounded.

\section{c. The Explosives Act}

This Act governs the use of explosives within Kenya and is applicable in this sector since coal mining requires the use of explosives. These explosives, however, can result in the caving in of the mine killing those inside or trapping them. The Act therefore makes it mandatory for mine operators to acquire a permit in order to access blasting materials. ${ }^{40}$

It is a crime for a coal mine operator to use blasting materials without a permit and is punishable by either a three thousand shillings fine or a one-year prison sentence, or both. ${ }^{41}$ Considering the dangers that are associated with blasting materials, the fine stipulated by the Act is too little and may not be adequate to deter coal mine operators from using explosives without a permit. Its punitive aspect is wanting.

\section{iii. Legal policies}

\section{a. The National Minerals and Mining Policy (Final Draft)}

The Policy was developed with the goal of coming up with an all-encompassing framework for managing Kenya's mineral resources. Strategies to be employed in the Policy include ensuring a socially acceptable balance between the impacts, both positive and negative of mining on the physical and human environment; ensuring that compliance of activities in the mineral sector are in line with the relevant health and safety legislation; promoting best mining practices

\footnotetext{
Section 50(1), Work Injury Benefits Act (Act No. 13 of 2007).

Section 50(2), Work Injury Benefits Act (Act No. 13 of 2007).

Section 9, Explosives Act (Chapter115, Laws of Kenya).

Section 12, Explosives Act (Chapter 115, Laws of Kenya).
} 
to ensure that mine closure plans and post-mining phases form integral part of the planning stage; develop in liaison with relevant institutions specific regulation for mining operations in environmentally sensitive areas such as forests reserves, nature reserves and national parks. ${ }^{42}$

In as much as there are quite a number of laws governing mining in Kenya, very little has been done, or proposed to be done to ensure that the safety and health of coal workers is protected. This leaves those working in mines susceptible to health hazards and other unsafe practises associated with mining. The laws have proved to be inadequate in ensuring the health and safety of those in mines. This is why the legislature needs to go back to the drawing board and come up with a policy and legal framework that addresses the health and safety of coal workers. This will help seal the loopholes in the mining laws and avert future tragedies in the sector.

\section{Salient Features of the Legal Framework Governing the Occupational Safety and Health of Coal Workers in Other Jurisdictions}

The right to safe and healthy working conditions is part of the broader right of everyone to the enjoyment of just and favourable conditions of work, enshrined in article 23 of the Universal Declaration of Human Rights ${ }^{43}$ (hereinafter UDHR), and article 7 of the International Covenant on Economic, Social and Cultural Rights ${ }^{44}$ (hereinafter ICESCR). UDHR provides that everyone is entitled to the right to work, to free choice of employment, to just and favourable conditions of work and to protection against unemployment. ${ }^{45}$ ICESCR $^{46}$ further reiterates the right to safe and healthy working conditions. It stipulates that all state parties will recognise the right of everyone to the enjoyment of just and favourable conditions of work which will ensure safe and healthy working

\footnotetext{
Section 2, National Minerals and Mining Policy (Final Draft) (2010).

Universal Declaration of Human Rights, 10 December 1948, 217 A (III).

The International Covenant on Economic, Social and Cultural Rights, 16 December 1966, 993 UNTS 3; Sensi S, "The adverse effects of the movement and dumping of toxic and dangerous products and wastes on the enjoyment of human rights." A paper presented at a high level expert meeting on the new future of human rights and environment: Moving the global agenda forward, held at Nairobi, November 30 - December 1, 2009.

45 Article 23, Universal Declaration of Human Rights, 10 December 1948.

46 International Covenant on Economic, Social and Cultural Rights, 16 December 1966.
} 
conditions. ${ }^{47}$ In the preamble to the International Covenant on Civil and Political Rights ${ }^{48}$ (hereinafter ICCPR), the parties outline the obligation of all states to recognise in accordance with UDHR, that the ideal of free human beings enjoying civil and political freedom and freedom from fear and want can only be achieved if conditions are created whereby everyone may enjoy their civil and political rights, as well as their economic, social and cultural rights.

The above international instruments show the importance the international community has accorded to the right of all persons to safe and healthy working conditions. With that in mind, this section of the article looks into the best practices employed by other states in grappling with the issue of occupation health and safety of coal workers. The article examines two jurisdictions namely; Australia and South Africa.

\section{i. Australia}

Australia has one of the most progressive occupation health and safety legislation in the world. Its legislation is based on the principles of risk management, worker participation and the duty of care and places the onus of providing safe workplaces on the operator of the mine site. ${ }^{49}$ Government inspectors act as both enforcers of regulations and mentors who encourage good health and safety performance. Further, enforcement protocols are generally risk-based, with action being defined by both the level and immediacy of the risk. ${ }^{50}$

In Australia, each state has come up with its own legal framework which incorporates different regulations that promote the development of management systems. However, there has been harmonisation of mining laws between the Australian states. These laws have been developed so as to be in line with the occupational health and safety laws in the country. ${ }^{51}$ This article examines the New South Wales mining legislations namely; the Work Health and Safety (Mines) Act $^{52}$ and the Work Health and Safety (Mines) Regulations. ${ }^{53}$ These pieces of leg-

\footnotetext{
Article 7, International Covenant on Economic, Social and Cultural Rights.

The International Covenant on Civil and Political Rights, 16 December 1966, 999 UNTS 171.

Cliff D, 'The management of occupational health and safety in the Australian mining industry' International Mining for Development Centre (2012), 3.

50 Cliff D, 'The management of occupational health and safety in the Australian mining industry', 3.

51 Work health safety (mines) legislation factsheet, http://www.resourcesandenergy.nsw.gov.au/ miners-and-explorers/safety-and-health/legislation/whs-mines on 15 December 2015.

52 Work Health and Safety (Mines) Act (2013) (New South Wales).

53 Work Health and Safety (Mines) Regulations (2014) (New South Wales).
} 
islation replaced the Coal Mine Health and Safety Act, 2002 and the Mine Health and Safety Act, 2004.

The main objective of the Act is the promotion of the health and safety of persons at work in mines or related places, by ensuring that measures are in place to eliminate risks and emergencies in the various workplaces in the mines. ${ }^{54}$

Part 5 of the Act touches on the safety and health representatives for coal mines. ${ }^{55}$ These representatives have the obligation of reviewing and implementing safety management systems which are required to be present in mines, to investigate any incidents or occurrences in the mines and to help train site and electrical safety and health representatives. ${ }^{56}$ Further, the representative can give directions to the operator of the mine to suspend operations if they are of the opinion that the mine has failed to comply with the occupational health and safety standards thus posing danger to the employees. ${ }^{57}$ Failure by the operator to comply with the directions of the representative results in a fine of AUD 10,000 payable if the operator is an individual and AUD 50,000 payable if the operator is a body corporate. ${ }^{58}$

Further, the Act provides for the appointment of mine safety and health representatives. ${ }^{59}$ These, in contrast to the industry safety and health representatives, have a more specific role as they are experts in a specific line of work. For instance, where electrical installations are required in the coal mine, an electrical safety and health representative would be the one to carry out the task and not a health safety and health representative. ${ }^{60}$

The Act establishes the Mine Safety Advisory Council. ${ }^{61}$ This council has the duty of advising the Minister on any policies that may be required in relation to the health and safety of workers in mines. ${ }^{62}$ Further, the Act establishes a Competence Board which oversees the development of standards of competence for persons working in mines in relation to their health and safety. ${ }^{63}$ The Competence Board also carries out due diligence on the competence of persons

\footnotetext{
Section 3, Work Health and Safety (Mines) Act (2013) (New South Wales).

Section 28, Work Health and Safety (Mines) Act (2013) (New South Wales).

Section 29(2), Work Health and Safety (Mines) Act (2013) (New South Wales).

Section 30, Work Health and Safety (Mines) Act (2013) (New South Wales).

Section 30(3), Work Health and Safety (Mines) Act (2013) (New South Wales).

Division 3, Work Health and Safety (Mines) Act (2013) (New South Wales).

Section 42(2), Work Health and Safety (Mines) Act (2013) (New South Wales).

Section 60, Work Health and Safety (Mines) Act (2013) (New South Wales).

Section 61, Work. Health and Safety (Mines) Act (2013) (New South Wales).

Section 67(1) a, Work. Health and Safety (Mines) Act (2013) (New South Wales).
} 
exercising functions in a mine ${ }^{64}$ and where it deems fit, it has the duty to advise the Minister on matters related to the competence required of persons to exercise any function in a mine. ${ }^{65}$

In order to exercise its functions effectively, the Competence Board may develop competence standards or cause them to be developed where there is need to do so. ${ }^{66}$ Finally, it is mandatory that the Competence Board provides an annual report to the minister, highlighting its activities during the preceding year. ${ }^{67}$

In order to ensure that the objectives of the Act are met, the Act also establishes the position of a regulator who advices the Minster and makes recommendations pertaining to the effectiveness of the work health and safety laws. ${ }^{68}$ The New South Wales Department of Industry acts as the regulator. The Department takes advice from the Competence Board on how to carry out its functions under the Act. In coal mines, their function is important as they determine the requirements for certificates of competence and conduction of examinations, and the issuing of certificates of competence and practicing certificates. ${ }^{69}$

Under the regulations, mine operators must develop and implement a safety management system as a means of ensuring that the safety and health of workers and that of others present in the mines is not jeopardised as a result of mining operations. ${ }^{70} \mathrm{~A}$ safety management system for a mine is the principal means of ensuring that a mine operates smoothly and safely. ${ }^{71}$ It harnesses various policies and procedures which provide a systematic approach to be followed by the mine operator in order to achieve and monitor effective levels of health and safety. This system has to be documented, should be clear and comprehensible and be made accessible to all persons who may want to access it. ${ }^{72}$

In most cases the safety management system will include specific strategies for hazards and risks at the mine such as mining hazard management strategies and controls strategies for emergencies, electricity, health, explosives, plant and other mechanical risks. The purpose of the safety management system is to set

\footnotetext{
Section 67(1) b, Work Health and Safety (Mines) Act (2013) (New South Wales).

Section 67(1) c, Work Health and Safety (Mines) Act (2013) (New South Wales).

Section 67(3) b, Work Health and Safety (Mines) Act (2013) (New South Wales).

Section 68, Work Health and Safety (Mines) Act (2013) (New South Wales).

Section 74, Work Health and Safety (Mines) Act (2013) (New South Wales).

NSW Department of Industry, Skills and regional development, mining competence board strategic plan to 2020, 14 December 2015.

70 Clause 13, Work Health and Safety (Mines) Regulations (2014) (New South Wales).

71 NSW Code of Practice, 'Safety management systems in mines' (2015).

72 NSW Code of Practice, 'Safety management systems in mines'.
} 
out in a structured and organised manner, various aspects of operations in the mines that affect the safety of workers and any other persons in the mine. ${ }^{73}$ Usually, a safety management system will document the following: a safety policy outlining how the operator intends to manage safety outcomes, how they will implement safe work procedures in the mines, how the mine will be managed and how resources will be allocated to handle safety matters, any consultation arrangements with workers and the coordination of activities of other persons who may be in the mine and finally, it outlines procedural issues such as the monitoring of health, incidents reporting, filing of records and maintenance procedures for the system. ${ }^{74}$ If a mine operator fails to come up with the system, they are liable to pay penalties. Where the operator is an individual, they are liable to pay a fine amounting to AUD 6,000 and where the operator is a company, it is liable to a fine of AUD 30,000. ${ }^{75}$

The regulations also requires mine operators to come up with emergency plans to cater for the mines. Failure to do so attracts penalties worth AUD 6,000 for individuals and AUD 30,000 in the case of body corporates. ${ }^{76}$ Normally, an emergency plan addresses the various response mechanisms in the case of an emergency and outlines probable triggers of the emergency plan. ${ }^{77}$ In coming up with the emergency plan, operators take special account of the nature of the operations, how complex the operations are and the possible risks that may arise as a result of the operations. ${ }^{78}$

The Act has yielded positive results in the state. Between 1 July 2013 and 30 June 2014, 16 mine workers died at work in mines in Australia. Out of this, only 3 of the fatalities occurred in coal mines in New South Wales. This is evidence of the efficiency of the legislation in place as compared to other countries with over hundreds of deaths in their mines. ${ }^{79}$

Further, the District Court of New South Wales now has jurisdiction to hear and determine all claims pertaining to the compensation of coal workers. In respect of compensation purposes, coal workers are treated differently as they retain certain rights to compensation which other workers do not. These, inter alia, include the entitlement to redeem lump sum payments as compensation

\footnotetext{
Work Health and Safety Regulations (2012) (South Africa), 'A guide to Chapter 10 - Mines'.

Work Health and Safety Regulations (2012) (South Africa), 'A guide to Chapter 10 - Mines'.

Clause 13, Work. Health and Safety (Mines) Regulations (2014) (New South Wales).

Clause 88, Work. Health and Safety (Mines) Regulations (2014) (New South Wales).

Clause 88, Work Health and Safety (Mines) Regulations (2014) (New South Wales).

Clause 88(3), Work. Health and Safety (Mines) Regulations (2014) (New South Wales).

http://www.mineaccidents.com.au/mine-events/disaster/au, on 15 December 2015.
} 
and the entitlement to the deemed total incapacity provision under the Workers Compensation Act. $^{80}$

\section{ii. South Africa}

South Africa has suffered numerous fatalities in its mining sector. This is in spite of mining being one of the cardinal economic activities. In 2009, mining contributed about $18.8 \%$ of the gross domestic product and created about one million jobs in the country. ${ }^{81}$ In the late $19^{\text {th }}$ Century, miners were exposed to multiple health and safety risks as mining had just increased to a more industrial scale. The safety of mines has since improved in the country. The South African Commission of Inquiry into Mine Safety and Health, in 1995, after carrying out studies concluded that dust exposure in mines had stagnated for 50 years. ${ }^{82}$

The International Labour Organisation undertook a survey of the number of fatalities related to work in South Africa. From the survey, they found that in 2001, close to 2,000 workers died as a result of work related accidents. From these, 288 died in mines. ${ }^{83}$ Given that miners account for less than $4 \%$ of the total workforce in the country, approximately $15 \%$ of work-related fatalities are associated with mining. ${ }^{84}$

In response to fatalities in mines, the mining legislation in South Africa had to be developed. In 1972, the report of the Roben's Committee, a commission of inquiry into health and safety at work in Britain, ${ }^{85}$ chaired by Lord Roben, laid the foundation of more comprehensive and systematic health and safety approaches. Lord Roben criticised the bias in the law in regard to safety and health as the law lacked provisions to address the same.

He called for expansion of occupation health and safety to take into account human factors associated with work, the interactions between employers and employees in matters of health and safety and the employer's duty in the management of occupational health and safety in his workplace. Further, he proposed that prescriptive legal provisions be replaced by performance or outcomes

\footnotetext{
80 http://www.judcom.nsw.gov.au/publications/benchbks/civil/mining_list.html on 15 December 2015.

81 Mining and minerals in South Africa, http://www.southafrica.info/business/economy/sectors/ mining.html on 15 December 2015.

82 Commission of Inquiry into safety and health in the mining industry, 1995, 54-55.

83 http://www.dmr.gov.za/mine-health-a-safety.html on 15 December 2015.

84 http://www.dmr.gov.za/mine-health-a-safety.html on 15 December 2015.

85 The Roben's Report, 1972.
} 
requirements, which were to be supported by a general duty of care placed on employers. ${ }^{86}$

As a result of this, in 1995, the South African Commission of Inquiry into Safety and Health in the Mining Industry, came up with a report recommending the promulgation of legislation to address occupational health and safety in mines, and to ensure that operators in mines take immediate steps in improving the standards of practice in the workplace and controlling health hazards. ${ }^{87}$

The Mine Health and Safety Act and its regulations of 1996, from the commission's findings, had the aim of ensuring that the health and safety of employees and other persons at mines was protected. ${ }^{88}$ These two pieces of legislations govern the occupational safety and health of workers in coal mines in South Africa. The Act stipulates that employers bear primary responsibility to ensure that there is a safe work environment. This means that they have to ensure that mines are designed and constructed in a manner that will provide a safe and healthy working environment. ${ }^{89}$ Further, employers are required to ensure they keep and maintain an annual health report, for which, if the employer is a body corporate with at least 50 employees then they shall publish and distribute it to their shareholders. ${ }^{90}$

Employers are also obligated to provide safety and health equipment to the employees. ${ }^{91}$ They should also ensure that the facilities are upheld in hygienic conditions. The employer should also provide sufficient protective equipment for the employees and make sure that the employees are aware of the proper use and maintenance of the equipment. ${ }^{92}$ Additionally, pursuant to section $8,{ }^{93}$ the employer is mandated to establish a policy pertaining to health and safety which outlines the organisation of work, the protection of both employees and nonemployees who may be affected by the mining operations. Under clause $3,{ }^{94}$ the employer has an obligation to publicly display the copy of the policy and must also generate copies for the representatives in the mines. This helps in ensuring the employees are informed of their rights relating to their health and safety.

86 Gunningham N and Johnstone J, Regulating workplace safety: Systems and sanctions, Oxford University Press, Oxford, 1999, 344-346.

87 Commission of Inquiry into safety and health in the mining industry report, 1995, 160.

88 Preamble, Mine Health and Safety Act (Act 29 of 1996) (As amended in 2008) (South Africa).

89 Section 2, Mine bealth and Safety Act (Act 29 of 1996) (As amended in 2008) (South Africa).

90 Section 2, Mine bealth and Safety Act (Act 29 of 1996) (As amended in 2008) (South Africa).

91 Section 6, Mine Health and Safety Act (Act 29 of 1996) (As amended in 2008) (South Africa).

92 Section 6, Mine Health and Safety Act (Act 29 of 1996) (As amended in 2008) (South Africa).

93 Section 8, Mine Health and Safety Act (Act 29 of 1996) (As amended in 2008) (South Africa).

94 Section 8(3), Mine Health and Safety Act (Act 29 of 1996) (As amended in 2008) (South Africa). 
The Act stipulates that workers have the right to participate in health and safety training. The onus to provide for this training is placed on the employer. ${ }^{95}$ Training provides employees with any information that may be required to undertake their duties without endangering themselves. This makes employees become familiar with occupational hazards posed by the mining environment and steps they can individually take to curb such risks. This training is free and therefore no employee is required to pay any sum for it. ${ }^{96}$ Training is carried out on different occasions. These include: Before employees commence the work, on intervals that may seem fit to the employer, before making substantial changes to mining equipment and before changes are made in relation to the employees' work. ${ }^{97}$ Further, records of all trainings must be kept by the employer.

The employer is further required to acquire the services, whether part time or full time, of an expert in the field of occupational hygiene techniques whose duty is taking an account of the hazards present in the mine and filing records of the same. ${ }^{98}$ Subsequently the employer is required to come up with a medical surveillance system of employees exposed to health hazards on requirement by law to do so or in response to an assessment conducted by him. ${ }^{99}$ The surveillance is appropriate considering the hazards. Further, the employer must acquire the services of a medical practitioner where necessary. ${ }^{100}$ This ensures that all possible health risks are countered appropriately and in a timely manner.

The Act also stipulates the necessity of approaches on risk management in addressing health and safety hazards. This is made possible by identifying the risks and hazards employees are exposed to while at work, assessing the risks, making a record of significant hazards and availing the records to the employees. ${ }^{101}$ A periodic review of records has to be undertaken by the employer in order to determine whether further control or elimination of risk is possible in future. ${ }^{102}$ The Principal Inspector of Mines has to be informed on any incident or occurrence resulting in injury or death of a person in a mine in order for them to instruct an inspector to carry out a parallel investigation of the incident with the employer. ${ }^{103}$

\footnotetext{
Section 10, Mine bealth and Safety Act (Act 29 of 1996) (As amended in 2008) (South Africa). Section 24, Mine bealth and Safety Act (Act 29 of 1996) (As amended in 2008) (South Africa). Section 10(3), Mine bealth and Safety Act (Act 29 of 1996) (As amended in 2008) (South Africa). Section 12, Mine bealth and Safety Act (Act 29 of 1996) (As amended in 2008) (South Africa). Section 13, Mine health and Safety Act (Act 29 of 1996) (As amended in 2008) (South Africa). Section 13, Mine health and Safety Act (Act 29 of 1996) (As amended in 2008) (South Africa). 1 Section 11(1), Mine health and Safety Act (Act 29 of 1996) (As amended in 2008) (South Africa). 102 Section 11(4), Mine bealth and Safety Act (Act 29 of 1996) (As amended in 2008) (South Africa). 103 Section 11(5) b, Mine bealth and Safety Act (Act 29 of 1996) (As amended in 2008) (South Africa).
} 
The Act establishes the Mine Health and Safety Council. ${ }^{104}$ It is a tripartite entity comprising of the state, the employer and labour members under the direction of the chief inspector of mines. The council has the task of advising the Minister on any legislations and research outcomes which are targeted at promoting the health and safety in the mines. Moreover, it oversees all the activities of its sub committees, holds a summit after every two years in which a review of the state of occupational health and safety in mines is undertaken.

The number of injuries and deaths in coal mines has significantly dropped in South Africa. For instance, in 2014, the number of fatalities in all mines was 84 being the lowest number ever recorded in the country. Of these, seven of the fatalities occurred in coal mines. This was a 93\% improvement in the safety of coal mines between 1993 and 2013, as fatalities have reduced from 90 to 7 fatalities. ${ }^{105}$ Cases of noise induced hearing loss have reduced from about 6,000 case recorded in 2003 to about 1, 200 cases which were recorded at the end of 2013. ${ }^{106}$

At the 2014 Mine Health and Safety Summit, the Mine Health and Safety Council said it would launch a Centre of Excellence in April 2015. This centre is aimed at spearheading the promotion of innovation by means of training and research carried out by mine workers. 'We need to reclaim our space as a country that leads in mining innovation and excellence, stated Mike Teke, President of the Chamber of Mines. ${ }^{107}$

As has been discussed, in the late $19^{\text {th }}$ Century when mining increased to a larger scale in South Africa, mine workers faced very high levels of risk both to their safety and health. However, with the introduction of laws such as the Mine Health and Safety Act and regulations; the safety performance of mines has shown great improvements and is definitely a step in the right direction.

From the two case studies - Australia and South Africa - the positive impacts mining legislations specific to the health and safety of workers in mines have had in those states is evident. Kenya ought to use this as a learning opportunity and come up with similar coal mining legislation that will adequately cater

\footnotetext{
Section 42, Mine bealth and Safety Act (Act 29 of 1996) (As amended in 2008) (South Africa).

105 http://www.southafrica.info/news/business/mine-deaths-27115.htm\#.Vk9_ mfkrK03\#ixzz3sZi08GAL on 10 January, 2016.

106 http://www.southafrica.info/news/business/mine-deaths-27115.htm\#.Vk9_ mfkrK03\#ixzz3sZi08GAL on 10 January, 2016.

107 http://www.southafrica.info/news/business/mine-deaths-27115.htm\#.Vk9_ mfkrK03\#ixzz3sZi08GAL on 10 January, 2016.
} 
for the persons who will be working in the coal mines in Mui basin.

\section{iii. Comparative study of the legal frameworks in Australia and South Africa}

The first aspect that is worthy of address is that of safety representatives in mines and their training. In accordance with the Mine Health and Safety Act (South Africa), mine safety representatives have to undergo some form of training. This is similar to the Occupational Safety and Health Act which stipulates the same. ${ }^{108}$ The training provided by the Mine Health and Safety Act (South Africa) is threefold. Firstly, workers should be trained to execute particular operations in means that not only ensure the protection of the worker alone but also preventing risks that may affect others in the mines. ${ }^{109}$ Secondly, training on commencement of the project and periodic trainings should be designed for all ranks of mine officials, taking into account the various risks to the health and safety of the persons posed in the mine. ${ }^{110}$ Thirdly, adult basic education training (ABET) which is a primary contributor to the intervention and minimization of health and safety risks in mines. ${ }^{111}$ Studies, however, have shown that neither the representatives themselves, nor the workers themselves, are fully aware of all these roles, functions and responsibilities. ${ }^{112}$

More so, in spite of legislation expressly providing for the requirement of undertaking training, there aren't any regulations or institutions in place to ensure that they are indeed carried out. The only thing made available is literature, which is of a technical nature discussing the use of specific equipment for health and safety, but there is very little, if any, information about training approaches and techniques. After various studies were carried out on the development of mining, some researchers came to the conclusion that historically, a fallacy existed claiming that lack of training did not in itself cause accidents or fatalities in mines. ${ }^{113}$

108 Section 9, Occupational Safety and Health Act (Act No. 15 2007).

109 Tuchten G, 'Concept development for facilitating the health and safety efficacy of South African mine workers' Doctoral Thesis, University of Pretoria, 31 August 2011, 124.

110 Tuchten G, 'Concept development for facilitating the health and safety efficacy of South African mine workers', 124.

111 Tuchten G, 'Concept development for facilitating the health and safety efficacy of South African mine workers', 124.

112 See Rees D, Ingham F, Bello B and Murray J, 'Awareness for persons affected by mining operations in South Africa', Mine Health and Safety Council and National Institute of Health (2007).

113 See Webber-Youngman R, and Van Wyk E, 'Incident reconstruction simulations - Potential impact on the prevention of future mine incidents' Journal of the Southern African Institute of Mining and Metallurgy (2013). 
Further, mining companies are considered reluctant to share information that can impact on their place in the market. ${ }^{114}$ This reason, inter alia, alludes to why mining companies over the years have been reluctant in training the representatives. According to Walters and Frick,

'The features promoting effectiveness of occupational health and safety in workplaces included, adequate training of persons in the workplace, interaction opportunities between employers and workers and mechanisms of channelling problems in the workplace and changes being made on the same. ${ }^{115}$

They maintain that the more this criterion is met in workplaces, the better the rates of detection and reduction of work hazards therein. ${ }^{116}$ However, this cannot be realised without the commitment of the management. Management commitment in improving the health and safety is important because it supports participative arrangements for health and safety and ensures efficiency and quality of production. Walters and Gourlay stated,

' $[\mathrm{w}]$ hatever the level of development of trade union organisation and worker representation on health and safety, it can never be a substitute for management organisation for health and safety. Without effective management systems for health and safety and a commitment to its continued prioritization, the role of worker involvement is severely constrained. ${ }^{117}$

Representatives therefore ought to enjoy the following rights so as to effectively carry out their duties: ${ }^{118}$ protection from any discrimination as a result of their representative role, paid time off to enable them to carry out their functions, paid time off in order to receive training; the right to information made available by the employer on current and future hazards to the health and safety of workers at the workplace, the right to inspect the workplace and any complaints from workers on issues of health and safety; the right to be consulted by the employer on all issues pertaining to his role and finally, the right to accompany health and safety authority inspectors when they inspect the workplace and to make complaints to them when necessary.

114 See Frankel P, Falling ground: Human approaches to mine safety in South Africa, Agency for Social Reconstruction Press, Johannesburg, 2010.

115 See Walters D and Frick K, Worker participation and the management of occupational health and safety: Reinforcing or conflicting strategies? Oxford University Press, Oxford, 2000.

116 See Walters and Frick, Worker participation and the management of occupational bealth and safety.

117 Walters D and Gourlay S, 'Statutory employee involvement in health and safety at the workplace: A report of the implementation and effectiveness of the Safety Representatives and Safety Committees Regulations 1977', 1990, 130.

118 International Labor Organization, Occupational Safety and Health Convention, No. 155 of 1981. 
The second aspect is that of the tripartite Mine Health and Safety Council which is also established by the Mine Health and Safety Act, and consists of members representing the State, employees and employers in the mining industry. This is also the case in New South Wales which has a Mine Safety Advisory Council. The Council has the task of advising the Minister on any legislations and research outcomes which are targeted at promoting the health and safety in the mines. The Chief Inspector of Mines is the chairperson of both the Mine Health and Safety Council and the Mining Qualifications Authority. The authority handles matters pertaining to the education and training needs in the mining sector.

In Kenya, the Occupational Safety and Health Act establishes the National Council for Occupational Safety and Health. The duties of this Council ${ }^{119}$ include advising the Minister on occupational safety and health policies to be adopted, formulating statutory proposals specific to occupational safety and health and promoting best practices regarding occupational safety and health. ${ }^{120}$ The interpretation section of the Act, however, defines the term 'Minister' as the Minister of Labour ${ }^{121}$ or now referred to as the Cabinet Secretary in charge of the Ministry of Labour, Social Security and Services. It is inconceivable that the Cabinet Secretary is able to sufficiently cater for all industries that require labour force in the country. Therefore, it would be prudent to follow South Africa and New South Wales and come up with a council specifically in charge of the safety and health in mines. This council, should be answerable to the Cabinet Secretary in charge of mining who is competent to handle the matter as it falls within their docket. It will also ensure that actual training of representatives is undertaken.

As was also evident in the mining legislations of New South Wales, the mining council will also ensure that safety management systems are present in mines. These systems are vital as they are the primary means of ensuring the safe operation of a mine. ${ }^{122}$ They will also ensure that the system is documented. Further, the council through its representatives will ensure that the system is understandable and easily accessible to those who might want to read it. According to Mwangi Rwenji, ${ }^{123}$ a mining engineer in Kenya,

\footnotetext{
Section 27, Occupational Safety and Health Act (Act No. 15 2007).

Section 27(1), Occupational Safety and Health Act (Act No. 15 2007).

Section 2, Occupational Safety and Health Act (Act No. 15 2007).

NSW Code of Practice, 'Safety management systems in mines' (2015)

Mwangi Rwenji is a mining \& metals engineer at JapakGIS limited.
} 
'Safety management systems are important as they introduce a standardized way of handling safety that eliminates the aspect of having to train, re-train and train again employees as the whole system becomes like a continuous training approach while at the same time meeting the objective of safety management. From this, we can see the vital role safety management systems will play in coal mines in Kenya.'

The final aspect to be discussed is that of compensation. The Work Injury Benefits Act provides that an employee is entitled to periodical payments equivalent to their earnings for suffering temporary total disablement due to an accident incapacitating them for three days or more. ${ }^{124}$ This compensation, however, is limited to a period not exceeding twelve months. ${ }^{125}$ On average, workers in Kenyan mines (inclusive of coal workers) earn about KES 81,030 per annum. ${ }^{126}$ Assuming the worker is temporarily disabled, they are only entitled to KES. 81,030 which will be paid through the course of the following year. From then, they are not entitled to any other payments from then. In New South Wales, there are two methods of paying compensation. The first is periodic payments to the worker at the rate of their current weekly wage for the first 26 weeks, and after 26 weeks, weekly payments up to a maximum payment of KES 42,697 per week, depending on the extent of the disability. The second involves indexed weekly payments made to a surviving dependent spouse, payable at KES 24,918 per week, which continues until re-marriage or the commencement of a de facto relationship or until the death of the spouse. ${ }^{127}$

\section{Conclusion}

Considering the delicate situation of the coal mining environment, a lot needs to be done to ensure the health and safety of the workers in Kenya. There is need to establish strong institutional, legal and policy frameworks as has been done in Australia and South Africa. This article therefore makes the following recommendations.

First, Kenya should enact an Act to deal exclusively and extensively with occupational health and safety of coal mine workers. Second, there should be a revision of the compensation amounts provided for by the Work Injury Benefits

\footnotetext{
Section 28(1), Work Injury Benefits Act (Act No. 13 of 2007).

Section 28(3), Work Injury Benefits Act (Act No. 13 of 2007).

26 http://www.africapay.org/kenya/home/salary/minimum-wages, on 10 January, 2016.

127 http://www.judcom.nsw.gov.ay/publications/benchbks/civil/personal_injuries_legal_framework. htlml on 10 January 2016.
} 
Act. Third, Kenya should also establish resilient institutions whose mandate is the regulation of the health and safety of mine workers. Fourth, there should be guidelines and directions encompassing duties of employers and employees in mining. Fifth, there should be a mining policy guiding on the protection of mine workers from possible health and safety hazards in their work area. Lastly, it should also be expressly provided in law for the provision of medical services in coal mines and even better a clinic to cater for the workers. 